\title{
Using a Systemic Functional Genre-Based Approach to Promote a Situated View of Academic Writing Among EFL Pre-service Teachers
}

\section{Uso de la lingüística funcional y las teorías de género para promover visiones situadas de la escritura académica entre los docentes de inglés en preparación*}

\author{
Doris Correa \\ doris.correa@udea.edu.co \\ Sandra Echeverri \\ sandra.echeverri@udea.edu.co \\ Universidad de Antioquia, Medellín, Colombia
}

This article reports partial results of a qualitative study which explored the gains and challenges encountered by two groups of English as a foreign language pre-service teachers from a public university in Medellin, Colombia, in developing a situated view of academic writing through a systemic functional genre-based instructional unit. The unit was part of a written communications course and used an approach called the teaching-learning cycle. Results from the study suggest that one of the main gains was related to pre-service teachers' emerging understanding of context, purpose, and audience. One of the main challenges concerned pre-service teachers' difficulty with shifting their former views of grammar as a fixed system of rules.

\footnotetext{
* $\quad$ Received: April 6, 2016. Accepted: November 15, 2016.

How to cite this article (APA 6th ed.):

Correa, D., \& Echeverri, S. (2017). Using a systemic functional genre-based approach to promote a situated view of academic writing among EFL pre-service teachers. HOW, 24(1), 44-62. http://dx.doi.org/10.19183/ how.24.1.303.

This article is licensed under a Creative Commons Attribution-NonCommercial-NoDerivatives 4.0 International License. License Deed can be consulted at http://creativecommons.org/licenses/by-nc-nd/4.0/.
} 
Key words: Academic writing, curriculum cycle, English as a foreign language, genre-based instruction, systemic functional linguistics.

Este estudio reporta los resultados parciales de una investigación cualitativa que exploró los beneficios y retos que dos grupos de docentes de inglés en formación de una universidad en Medellín, Colombia, experimentaron para desarrollar una visión situada de la escritura académica a través de una unidad pedagógica diseñada con base en las teorías de género y la lingüística sistémica funcional. De acuerdo con los resultados del estudio, una de las principales ganancias estuvo relacionada con la comprensión de contexto, propósito y audiencia, y uno de los principales retos tuvo que ver con la dificultad de los docentes en formación de cambiar su visión de la gramática como un sistema de reglas fijas.

Palabras clave: ciclo curricular, escritura académica, inglés como lengua extranjera, lingüística sistémica funcional, metodología de géneros.

\section{Introduction}

Recognizing the multiple challenges that academic genres may have for university learners in general, and university learners of English as a foreign language (EFL) in particular, many universities across the globe offer writing courses in which learners receive instruction on how to write these genres in English (Defazio, Jones, Tennat, \& Hook, 2010; Matsuda, 1999, 2006). Unfortunately, in many of these courses, teachers often take a cognitive (Johns, 1997; Silva \& Matsuda, 2002) as opposed to a situated sociocultural approach (Gebhard \& Harman, 2011; Hyland, 2003, 2004; Johns, 2002; Martin, 2009). That is, they encourage learners to see academic writing as a fixed activity the structure, grammar, and lexical forms of which are unchangeable across different contexts, purposes, and audiences (Johns, 2011). They do not promote a view of academic writing as a situated practice, the lexical, grammatical, and textual features of which vary across these variables (Butt, Fahey, Feez, Spinks, \& Yallop, 2000).

A pedagogy that not only familiarizes learners with the academic genres that "have accrued cultural capital" (Hyland, 2003, p. 24) in their particular fields of study but that also provides them with a more situated view of writing is systemic functional linguistics (SFL) genre-based instruction (GBI). Although the pedagogy has been widely used with English as a second language (ESL) and EFL learners in university settings (Chaisiri, 2010; Yasuda, 2011), in Colombia, in particular, there are no published studies of its use in EFL courses at this educational level. The closest study is that conducted by Chala and Chapetón (2013) at a modern languages program at an unknown university. However, this study is based on "Widodo’s (2006) proposal of a genre-based lesson plan" (Chala \& Chapetón, 2013, p. 131), not on SFL genre-based theories. Besides, it focuses on the role of GBI in the production of argumentative essays, rather than on how an SFL GBI approach could actually help the EFL 
learners adopt a more situated view of academic writing, which would allow them to meet the demands of their university courses and professional work. Consequently, little is known about the usefulness of this approach for the achievement of these particular purposes in the Colombian EFL higher education context.

To fill this gap, in the spring of 2011, a team of four teacher educators and researchers from a public university in Medellin, Colombia, designed a qualitative study which explored the gains and challenges that two groups of EFL pre-service teachers experienced in getting a more situated view of academic writing as they took part in an SFL genre-based curricular unit. The specific question addressed by the study was: What are the main gains and challenges EFL pre-service teachers encounter in developing a situated view of academic writing as they take part in this unit? The setting for the study was a level two Written Communications course taught by two of the team members, Tatiana and Sofía. ${ }^{1}$

To teach the course, the teacher educators used a particular model proposed by SFL genre-based scholars (Butt et al., 2000; Derewianka, 2004; Gebhard \& Harman, 2011; Martin, 2009; Schleppegrell, 2004; among others) called the teaching-learning cycle (Gebhard \& Harman, 2011; Macken-Horarik, 2002; Martin, 2009), the curriculum cycle (Derewianka, 2004), or the genre-based cycle (Feez, 2002). The purpose of this article is to report on one of the main gains and one of the main challenges the pre-service teachers encountered in developing a situated view of academic writing through the use of this particular model.

To achieve this purpose, the article first provides a brief overview of SFL genre-based theories and their view of academic writing. Then, it describes the steps of the teachinglearning cycle that SFL genre-based scholars use to promote this view. Next, it explains how these steps were applied in two sections of a level two Written Communications course during a unit on information reports. Finally, the article presents the research study, explaining the data collection and analysis procedures employed, the main gain and challenge that preservice teachers experienced throughout the unit, and the implications and conclusions that can be drawn from this.

\section{SFL Genre-Based Theories}

Genre theories include at least three different perspectives or schools: English for specific purposes (ESP), new literacy studies (NLS), and systemic functional linguistics, or the Sydney school (Hyland, 2003; Hyon, 2002; Johns, 2002; Lee, 2012). According to Hyland (2002, p. 115), of these schools, SFL has been the most committed to using a "systematic model of language" and a "metafunctional grammar" to teach English learners how to use

To protect the identity of participants and researchers in this study, all names have been replaced by pseudonyms. 
academic genres. SFL is a school based on Hallidayan functional linguistics (Halliday, 1978) and sociocultural theories of learning (Vygotsky, 1978), which "stresses the purposeful, interactive, and sequential character of different genres and the ways language is systematically linked to context through patterns of lexico-grammatical and rhetorical features" (Christie \& Martin as cited in Hyland, 2003, pp. 21-22).

To SFL scholars, the forms and structures of academic genres are not fixed but situated. That is, they cannot be memorized as some writing instructors who adhere to cognitive theories will have their learners think. They have to be decided upon consideration of three variables: context, purpose, and audience. The following paragraphs provide more details about these variables and their role in promoting a situated view of academic writing. They also describe the pedagogical model that SFL genre-based scholars have used to promote this view.

\section{SFL Genre-Based Scholars'Views of Academic Writing}

To SFL genre-based scholars there are at least three variables that have to be considered when writing academic texts. These are context, purpose, and audience. Context refers, among other aspects, to where the genres are used (e.g., the university, conference presentations, everyday life). Context-wise, genres can be classified into two types: academic and everyday (De Oliveira \& Lan, 2014). Academic genres require both extensive practice and explicit instruction since they contain "language patterns [that] are often unfamiliar to adolescents and present significant comprehension challenge" (Fang \& Schleppegrell, 2010, p. 588). Indeed, "they are abstract, technical, and metaphorical, increasingly infiltrated by valorized scientific and bureaucratic discourses" (Rose as cited in Hyland, 2002, p. 125). For instance, they use the declarative mood more than the interrogative and imperative moods. They utilize more complex clause structures, pack more information into each clause, and have a greater concentration of embedded clauses. Moreover, they employ less conjunctions and pronominal subjects as themes; and deploy less concrete lexis and clauses (Schleppegrell, 2004).

Purpose is related to the function of genres. These can be, for example, to relate a set of facts (reports), to explain and interpret a phenomenon (explanations), or to argue why a thesis has been proposed (expositions) (Butt et al., 2000). Depending on these purposes, they deploy particular configurations of lexical grammatical and textual features. Reports, for example, are identified by their use of generalized (e.g., newspapers, volcanoes, the royal family) instead of specific participants (The Times, Mt. Vesuvius, Queen Elizabeth), timeless verbs in simple present tense, and relational and material processes (Derewianka, 2004).

Audience is connected to the community to which texts are directed. Hence, although all information reports share some common lexical, grammatical, and textual features, 
disciplinary distinctions exist. For example, while reports in science have a rigid structural organization, employ extensive technical terms, timeless verbs in simple present tense, and a large percentage of relational process clauses (Schleppegrell, 2004), reports in the humanities may contain less extensive technical language, have a more flexible organization, and allow for agency to be displayed in the writing.

In sum, to SFL scholars, there are no rules that can be applied to all texts across contexts, purposes, and audiences. Each of these variables has to be considered by writers in determining the lexical grammatical and textual configuration of their texts if they want these texts to be accepted by the discourse communities for which they are being written. To help learners with this task, SFL genre-based scholars have created "a schema for sequencing tasks leading students to write in various genres on their own" (Hyon, 1996, p. 713). Such a schema has been given different names among which is the teaching-learning cycle (Gebhard \& Harman, 2011; Macken-Horarik, 2002; Martin, 2009). The next section provides a brief overview of the main foci, goals, and stages of this cycle.

\section{The Teaching-Learning Cycle}

The teaching-learning cycle is "an interactive process of contextualization, analysis, discussion, and joint negotiation of texts" (Hyland, 2002, p. 126). According to Gebhard and Harman (2011), its main goal is "to expand students' meaning-making repertoires by providing them with models, explicit instruction, and critical analyses of authors' and their own semiotic choices as they learn to interpret and produce academic texts in school" (p. 49). The model draws mainly on Halliday and Vygotsky (Hyland, 2003). As it draws on Halliday (1978), it is concerned with "the relationship between purpose, audience, and linguistic choice" (Yasuda, 2011, p. 112). Since it also draws on Vygotsky (1978), it emphasizes collaboration between learners (Feez, 2002), and between teachers and learners, with teachers scaffolding or supporting learners as they move through the different stages of the cycle.

These stages are preparation, modeling of text, joint construction, and independent construction (Derewianka, 2004). In the preparation stage, teachers negotiate the topic of the unit with the learners and plan activities to familiarize learners with the topic of their interest the genre (Gebhard \& Harman, 2011) and the vocabulary and grammar needed to discuss it (Butt et al., 2000).

In the second stage, modeling, teacher educators use sample texts to help learners understand the overall purpose of the text and the set of stages that help it achieve its purpose. They also examine with learners the function or purpose of each stage and the language features (e.g., passive or active voice, personal pronouns or abstract nouns, technical vocabulary, nominalizations, grammatical metaphors, tense and cohesive devices) associated with that function (Derewianka, 2004; Hyland, 2004). 
In the third stage, joint construction, learners construct a similar text with the whole class, a small group, or the instructor, taking into account the knowledge of the topic that was built during the first stage and the schematic structure and linguistic features discussed in the second stage (Butt et al., 2000). Before undertaking this task, however, they identify and conduct research on their own topic, and organize the information found in charts, matrices and so on (Derewianka, 2004).

Finally, in the fourth stage, independent construction, the instructor and peers support learners in the drafting, revising, and editing of these texts (Gebhard \& Harman, 2011), providing each other with feedback not on vocabulary, spelling, and punctuation errors, as is normally done in cognitive approaches, but on how the text could more effectively both achieve its purpose and address its audience (Derewianka, 2004).

By and large, then, the teaching-learning cycle, then, is a four-stage pedagogical tool which emphasizes collaboration between learners and between teacher and student. Such collaboration happens through a process of scaffolding in which learners are supported with different tasks as they move from one stage of the cycle to the next.

\section{Setting}

As explained earlier, the setting for this study was a level two Written Communications course offered in the spring of 2011 to pre-service EFL teachers at a university in Medellin, Colombia. The course lasted 18 weeks and was divided into two sections of 23 and 15 preservice teachers each, according to their time availability. The main aim of the course, as stated in the syllabus, was to familiarize these pre-service teachers with two different types of texts: information reports and argumentative essays. Due to space constraints, this article only describes one main gain and one main challenge experienced by the pre-service teachers during the unit on information reports.

The course instructors, Tatiana and Sofía, were two recent graduates from the EFL teacher preparation program, who had been hired as adjuncts to teach the level two Written Communications course. They had learned about SFL GBI through their participation in a study group led by Diana and Hernán, and had become so interested in the topic that they asked the latter to help them with the application of these theories in their course. Diana and Hernán were two senior full time faculty members who were eager to put these theories into practice. They not only assisted the teacher educators with all class and research activities but also acted as critical friends since they watched the class videos each week and brought their comments, questions, and suggestions to the weekly team meetings, so that the teacher educators would have another perspective on what had happened in class and could take timely corrective actions, if necessary. 
The pre-service teachers were a group of 20 men and 18 women, ranging from 17 to 38 years old, who, as described in the introduction, had for the most part been exposed to cognitive approaches to writing, as described in the introduction, through their school and university EFL courses, according to the report they made on the first day of classes.

\section{The Unit on Information Reports}

The unit on information reports lasted nine weeks during which Tatiana and Sofía taught 18 two-hour sessions each. It started with an overview of the unit and an exploration of the pre-service teachers' experience both with writing for other courses, and with information and communications technology (ICT) tools for learning and teaching a foreign language, the topic that would be proposed for the unit. It proceeded with an explanation of the new approach that would be followed and how it differed from the traditional cognitive approaches to which they were accustomed. It ended with the presentation of the research project and of all the ethical considerations of which they had to be aware before signing the consent forms.

Next, teacher educators moved on to negotiate with the pre-service teachers the endproduct for the unit, for which they proposed a blog compiling all the information reports written by them throughout the unit. The topic for such reports would be different ICT tools that EFL learners and teachers could use to learn and teach the language. Once preservice teachers were on board with these ideas, teacher educators proceeded with the implementation of the cycle.

As recommended by Derewianka (2004), the preparation stage of the cycle began with some activities intended to develop knowledge of the chosen topic and of the vocabulary and grammar teachers needed to write their information reports. Such activities included presentations of possible applications about which they could write; analysis of information reports they had read for homework in terms of technical vocabulary use; and group reading of different applications to teach and learn English.

The second stage of the cycle, modeling, comprised a series of activities intended to get pre-service teachers to understand how context, purpose, and audience influenced and were influenced by the language features of texts. These activities included whole class and small group analysis of the lexical, grammatical, and textual features of different everyday and academic genres such as information reports and argumentative essays. To model this analysis, teacher educators considered four different aspects: (a) their overall purpose, and the purpose of each stage or section of the text; (b) the kind of information provided in each stage; (c) the language deployed by the writers to achieve each of the purposes (e.g., types of subjects, verbs, complements, vocabulary, voice and tenses used); and (d) their clause structure (e.g., simple, compound, and complex clauses; long clauses that packed 
information in one single clause; piled up adjectives before the noun; and use of a series of relative clauses as post-modifiers).

Upon completion of this modeling, the teacher educators asked the pre-service teachers to perform the same kind of analysis with other sample texts, and to present this to the whole class. They also provided them with practice on how to construct the types of clauses that the sample texts contained using the new vocabulary found. When this practice was over, the teacher educators asked the pre-service teachers to get together in small groups and start a search on the web for information about similar applications, and to choose one about which they wanted to write.

Then, the third and fourth stages of the cycle began. These last two stages of the process aimed to provide pre-service teachers with the opportunity to practice writing an information report with substantial scaffolding and feedback in the beginning and less support at the end. To achieve this objective, teacher educators modeled how to skim and scan the information, how to construct a concept map of the information found, how to build an outline of the paper, and how to draft, proofread, and edit the different sections. As teacher educators took each of the steps, they allowed pre-service teachers to practice them by building a class information report. Then, they invited pre-service teachers to apply what they had learned in class to the construction of their own information reports.

Once the first drafts were completed, the teacher educators had the pre-service teachers provide feedback to one another, do a self-assessment of their writing, and attend individual feedback sessions with them. For all this, they used a series of rubrics that the team prepared. When the final draft was completed and approved, the teacher educators asked the pre-service teachers to send them to Hernán and Diana for publication on the blog. By the end of the unit, the pre-service teachers from both sections of the course had produced 21 information reports on different applications for teaching and learning languages. These were: Babble, BBC Learning English, Busuu.com, Cramster, Elllo, ESL POD, Facebook, Grammarmancomic.com, Hot Potatoes, Livemocha, Lyrics Training, Photostory, Photobistory, Randall's ESL Cyber Listening Lab, Skype, Starfall.com, Tell Me More, US A Learns, Voxopop, Writingfun.com, and Yappr.com.

\section{Method}

The study reported here can be described as qualitative. This type of study, as described by Patton (as cited in Suter, 2012, p. 347), aims to "to uncover emerging themes, patterns, concepts, insights, and understandings," uses multiple sources of evidence, often studies small groups to have better arguments for its confirmability, and focuses on natural settings. Accordingly, this study aimed at uncovering, through multiple sources of data, some emerging insights into how useful an SFL GBI approach could be in promoting a more situated view 
of academic writing among two groups of EFL pre-service teachers who shared the natural setting of a written communications course.

\section{Data Collection and Analysis}

Data collected for the study included video-recordings, samples of the pre-service teachers' work, and audio-recordings of all the meetings held by the team. Video-recordings comprised footage of two events: (a) the classes taught by each teacher educator throughout the semester in each section of the course, and (b) the two end-of-term group interviews carried out with all the pre-service teachers enrolled in each section of the course. Samples of the pre-service teachers' work were compilations of the assignments they did to create their information reports (e.g., the graphic organizers, outlines, and drafts of the papers they wrote in both sections of the course) and the rubrics they filled out to provide peer feedback and to self-assess their work. Audio-recordings included 14 recordings of all of the weekly meetings the team held to prepare the course syllabus and each of the class activities, to discuss gains and challenges and to modify the activities, as needed.

Data were analyzed using both inductive and deductive approaches (Suter, 2012). For example, to analyze videos of class sessions, Diana and Hernán looked for how the approach was helping pre-service teachers gain an understanding of context, purpose, and audience (deductive). However, they also allowed the data to "speak for themselves" (Suter, 2012, p. 346) (inductive) by pointing to other gains and challenges that needed to be addressed during the course. Video-recordings of group interviews were analyzed similarly but only at the end since this was when they took place. They provided researchers with the opportunity to have pre-service teachers' self-report on their gains and challenges in terms of academic writing.

Audio-recordings of the team meetings were analyzed mostly deductively through a chart which consigned the gains and challenges of the pre-service teachers in the abovementioned three areas. Finally, the samples of pre-service teachers' work were analyzed; first inductively as they were collected, so that the teacher educators could help pre-service teachers with a wide range of issues that were not necessarily connected to situation, purpose, and audience. Then, they were analyzed deductively in terms of gains and challenges with these three concepts. In order to achieve trustworthiness (Suter, 2012), once all data had been analyzed individually, the authors proceeded to their triangulation and to the drafting of the findings.

\section{Results: Understanding Writing as a Situated Social Practice}

The analysis of all the data collected during the unit on information reports suggests that the EFL pre-service teachers participating in this study experienced a series of gains and 
challenges in terms of understanding academic writing as a situated social practice that varies according to context, purpose, and audience. One of these main gains and one of these main challenges will be described in the following sections.

\section{Main Gain: Understanding Context, Purpose, and Audience}

One of the most important gains of the unit on information reports had to do with pre-service teachers' emerging understanding of context, purpose, and audience. This was evident in the videos of classes, the audios of the feedback sessions, and the EFL pre-service teachers' final information reports.

Understanding context. In terms of context, for example, both videos of classes and audios of feedback sessions show the EFL pre-service teachers offering to shift the connectors they had initially used in their drafts for others that in that moment sounded more "academic" such as moreover or furthermore. Also, on several occasions, they pointed out how the sources they consulted used the pronoun you or we when they could have used "more technical nouns" to make the text sound more academic. These two facts, although not reflective of a full understanding of context, did suggest to the team an emerging awareness on the part of the pre-service teachers of the particular context within which they were writing.

Finally, in the final drafts of their information reports, most pre-service teachers revealed an attempt to use academic language, as opposed to everyday language. Indeed, although in most of these texts there were instances of academic language being mixed with everyday language, there were also instances of pre-service teachers trying to deploy the type of language that was seen in the sample information reports that they had analyzed in class, and that Tatiana and Sofía had insisted on during the feedback sessions. That is, there were generic or abstract subjects; packs of information in one single clause; nominalization; chains of adjectives and nouns as noun pre-modifiers; relative clauses as verb post-modifiers; and different types of connectors for summarizing, making contrasts, and adding information, among others.

Two examples of this are the first clauses of the grammarcomic.com and the Livemocha information reports, where the authors defined the application. Here are some excerpts:

Livemocha is a very good popular, free language learning website, where you learn other languages by taking online courses and improving your speaking skills by interacting with native speakers (Information Report, Final Draft, Karina and Humberto; May 16, 2011) 
Photo story is a free, easy, tool application created by Microsoft, which gives the opportunity to learn and create stories developed step by step with digital photos and pictures in a easy and fun way. (Information Report, Final Draft, Valeria and Natalia; May 16, 2011) ${ }^{2}$

In these two excerpts, although at least one of the teams used the subject pronoun you which is more common in everyday than in academic language, they also used generative subjects (e.g., Livemocha, Photo story). Besides, they incorporated chains of adjectives and nouns as noun pre-modifiers (e.g., good popular, free language learning website; free, easy, tool application). Finally, they inserted relative clauses to expand nouns (e.g., "where you learn other languages by taking online courses and improving your speaking skills;" "which gives the opportunity to learn and create stories developed step by step with digital photos and pictures in an easy and fun way").

Understanding purpose. Concerning purpose, videos of classes and audios of feedback sessions show that the EFL pre-service teachers began to notice how linguistic choices helped the authors achieve particular purposes. In the video of Sofía's March 1 class, for example, when Sofía asked the pre-service teachers to point out where in one of her sources of information on Audacity they were able to see the purpose of the text, one of the pre-service teachers stated it was in paragraph 2 since in this paragraph the author was trying to convince the reader to use Audacity when he wrote "I think Audacity is really a sharp old bird. I've never seen a better audio editor before” (Video 2, Sofía’s class, March 1).

Also, after the feedback session with Sofía on March 29, one of the pre-service teachers (Carolina) questioned the title that she and her partner had chosen for their information report based on the fact that it did not reflect their purpose.

Carolina: My question is if we should just put the name of the program or try to motivate the reader, saying, for example, ESL Pod_-A Tool for Teaching and Learning.

Sofía: what is the purpose?

Carolina: call reader's attention.

Sofía: What for?

Carolina: to get them to read the text and, like waken their curiosity as to how this tool can be used in the process of teaching and learning a second language. ... Then, this title is not good.

(Carolina, Audio of Feedback Session with Sofía; March 29, 2011)

Finally, in the final drafts of their information reports, the pre-service teachers made consistent efforts to achieve the purpose of the text of informing EFL teachers and learners

All excerpts and quotes in this article follow the wording, spelling and interior punctuation of the original source. 
of applications they could use for learning and teaching English. In the final draft of the Facebook text, for example, after a feedback session in which Tatiana told the three authors that their text was not meeting its purpose since it was focused on the history of the application more than on its uses for EFL teachers and learners, the authors included several clauses in which they tried to meet the purpose by specifying the uses of the applications for the two groups of people being discussed.

For learners, there are many possibilities, for example games such as UNO, Farmville, Zinga Poker provide the option to talk to people around the world, practice their language skills, or increase vocabulary. For example, users of Farmville expand their vocabulary related with the farm life.

Teachers also have the opportunity to use Facebook as a teaching tool. For example, they can create groups with discussion forums on specific topics using English as the language to post comments. They can also post videos or links in their wall as assignments for their students to do specific activities around them. (Information Report, Final Draft, Camilo, Álvaro, Alejandro; May 16, 2011)

Understanding audience. As for audience, videos of classes and audios of feedback sessions show how the EFL pre-service teachers began to gain awareness of audience, and how this awareness impacted the linguistic choices they made. During the March 24 class session, for example, when Tatiana asked pre-service teachers for feedback on her draft, they suggested that she incorporate in it either instructions on how to use Audacity or links to where readers could find this information "because people won't know how to use it or how to download it" (Video 2, Tatiana's class, March 24). They also suggested that she include in the last paragraph details that were useful to EFL learners since this only included information useful to teachers.

Similarly, during the feedback session held by Sofía on April 5, the pre-service teachers working on the Busun application asked Sofía if they could use the pronoun you in the "uses section" and the "advantages section" of the report "to be closer to the reader," and then use "technical words and impersonal style" in the features sections (Nelson and Julieta, Audio of feedback session with Sofía, April 5). Although Sofía did not completely agree that the use of personal pronouns would be better for these sections, she was glad to notice that the teachers were able to see the different types of distance that was created with regard to the audience when using these types of pronouns.

Finally, the analysis of the information reports shows that even though the pre-service teachers used various subjects in their information reports such as you, users, and people, most of them were clear that their intended audience was EFL learners and teachers. This was evident in the fact that most of the information provided, apart from that in the first section of some of the reports which referred to history of the application, was pertinent to mostly this population. 
In the following paragraph from the $B B C$ Learning English information report, for example, even though in the second clause the authors use the word "users", by the fourth clause, it becomes obvious that the users whom the authors are addressing are English learners. Then, by clause five, it is clear that they are also addressing English teachers.

These activities can be also downloadable from the web page and they can be available for users who get access when they are not on internet. They can go from written media as classic books, stories, jokes, anecdotes, biographies, speeches, legends, appointments to audiovisual media as series, radio program and songs and even get access to groups of conversation. But sections are not only for those interested in learning English; it is also quite helpful for those who want to teach it by giving them several tools which could make this work easier. (Information Report, Final Draft, Mariana and Mónica; May 16, 2011)

\section{Main Challenge: Shifting Former Views of Grammar}

One of the main challenges that some of the EFL pre-service teachers faced in developing a view of writing as a situated social practice was shifting their former view of grammar as a set of rules to a view of grammar as a system of choices. This difficulty was reflected mostly in the videos of Tatiana's classes, and in the end-of-term group interviews. In one of the videos of Tatiana's classes, for example, one could observe two pre-service teachers asking to be taught the rules surrounding the construction of the grammatical features they saw in the sample texts (e.g., chains of adjectives, relative clauses) and the other teachers supporting them. The team took this request to mean that the pre-service teachers still thought grammar could be taught in isolation since what they were asking for was general rules which they could apply to every text they encountered. Nonetheless, they complied and brought handouts with explanations of the rules to the next class.

Two months later, in another video of Tatiana's class, the EFL pre-service teachers could be seen asking Tatiana to collect their mistakes and sustain whole class grammar lessons in which she explained how to correct the grammar mistakes the different groups were making during the production of their information report drafts. Given the myriad of grammar topics that would need to be covered, the short amount of time that was left for the unit, and her conviction that whole class grammar sessions would only reinforce the idea that learners had of grammar as a rigid set of rules, Tatiana decided to have a talk with them instead. She told the pre-service teachers that she understood their frustration with the lack of whole class grammar explanations since she knew this was what they were used to in these courses. Nonetheless, as explained during the first day of classes, the SFL genre-based approach the team was taking was based on a view of grammar as a system of choices made within the context of specific texts. Therefore, she would address their grammar concerns in their group conferences. 
In spite of the conversation, during the end-of-term group interview, four pre-service teachers from Tatiana's group complained about the lack of grammar lessons in which they were both pre-taught the structures they would need to use later (2 learners) or taught as a whole class the structures they were misusing in general (4 learners).

In class, you should have open a space and said, 'ok, these are the most common mistakes you are making, this is what you are failing to do, these are the doubts everybody has', and also explained those structures we should already know according to our level, so we could have a more appropriate handle on the grammar part. (Yenny, End-of-term Group Interview, Tatiana’s Group)

Although up to that point, Sofía's group had not voiced any complaints regarding this point, during the end-of-term group interview one pre-service teacher from this group also raised his hand to request whole class grammatical explanations of the most common mistakes found in their texts.

I think it would be interesting to take the most common mistakes from each writing piece and each text in the process and to explain those topics, do you know what I mean? (Pedro, End-of-term Group Interview, Sofía's Group) ${ }^{3}$

Upon hearing these complaints, Diana, who was doing the end-of-term group interviews with Hernán in both sections of the course, explained to pre-service teachers from both groups, as Tatiana had done before, that the model they were using tried to encourage a view of grammar as a resource for accomplishing specific purposes inside particular contexts. Therefore, explaining grammar points in isolation whether it was before beginning to write or during the writing process was not consistent with this view. However, the pre-service teachers who had proposed the idea did not seem very convinced and the team left the room feeling that the unit had been unsuccessful in getting at least some of the pre-service teachers to develop a more situated view of grammar and, by extension, of writing.

\section{Discussion}

As seen in the previous section, one of the main gains experienced by this group of EFL preservice teachers in developing a view of academic writing, particularly information reports, as a situated social practice, refers to teachers' understanding of context, purpose, and audience. Even though the understanding of these concepts was only emergent in the sense that the pre-service teachers still grappled with aspects such as how to be consistent in their use of academic language, or how to refer to their audience, to name two, this finding was very significant.

This excerpt and the previous one have been translated from Spanish. 
Indeed, it showed that with an SFL GBI approach EFL pre-service teachers are able to consider aspects of writing that go beyond completion and correctness and ask questions that they have not asked before about the texts they read and write. These questions include but are not restricted to those that the EFL pre-service teachers in these groups were asking at the end of the unit: How much does this title catch the readers' attention? How does choosing a pronoun instead of a technical word as a subject separate or shorten the distance between me and my reader? What other connectors and words can I choose instead of these to sound more academic?

In Colombia, the writing approach we have used for most of these university EFL writing courses does not promote this type of questions. It has mostly focused on accuracy rather than on meaning, and it has "foreground[ed] 'everyday' uses of writing while insisting on formal conventions" (Achugar, Schleppegrell, \& Oteíza, 2007, p. 19). As such, when EFL learners come out of these courses, they are mostly worried, as the EFL pre-service teachers in this group were at the beginning, about using "correct" grammar forms. They are also unaware of differences in register and how these may both reflect and influence the lexical, grammatical and textual choices they make.

Awareness of these aspects would help EFL learners understand that even though there are some configurations of features that are common to each genre, multiple variations exist across different contexts, purposes, and audiences, and that they need to be attentive to these. It would also allow them to recognize that a successful text is not that which lacks spelling, punctuation, or grammar mistakes but that which is able to make its author pass for a member of the discourse community in which it is received.

For EFL learners who are going to be English teachers, it is even more important than for regular English learners to understand these concepts since they are going to be the ones in charge of preparing the new generations of EFL writers. These generations will see writing the way EFL educators see it. Therefore, if what EFL teacher educators look at when they take their EFL pre-service teachers' texts is how much spelling and punctuation mistakes these texts have, this is what the EFL pre-service teachers will be concerned about when they write and when they become EFL teachers. Conversely, if what EFL teacher educators notice when they look at these texts is how the lexical, grammatical, and linguistic choices are appropriate to context, how they address a specific audience, and how they help EFL pre-service teachers achieve their general and specific goals, this is also what the pre-service will learn to focus on.

As for the challenges that the EFL pre-service teachers experienced with shifting from a view of grammar as a fixed set of rules to a view of grammar as a system of choices that varies according to context, purpose, and audience, this finding is also very significant. It not only shows the struggles that this particular group of EFL learners may experience with an SFL genre-based 
approach to grammar but also points to the need for EFL teacher educators to start approaching grammar in a more functional, less structural way from the beginning of the program.

When EFL pre-service teachers, as was the case of these, are used to seeing grammar as a prerequisite for writing, and as the obvious focus of writing feedback, it is difficult for them to make the switch and to start seeing grammar as a system of "choices that contributes to the effectiveness of their texts and helps them gain control of their writing" (Schleppegrell, 2004, p. 159). Conversely, when EFL pre-service teachers are used to dealing with grammar from a functional perspective, they understand that "focus on grammar does not mean learning the parts of speech in isolation from the texts they create and the meanings they make" (Schleppegrell, 2004, p. 148). Similarly, they do not request lessons in which the grammar that is going to be used is covered or their "grammar mistakes" are addressed. They understand that teacher educators cannot "separate the language from whole texts where the grammar is meaningful" (Schleppegrell \& Go, 2007, p. 538), and that there are no mistakes in grammar, only choices that match or fail to match the context, purpose, and audience for which they are written.

This does not mean, however, that in an SFL GBI approach, there are no grammar lessons. It only means that these lessons are not taught separately from the context of the texts being analyzed or produced. They are taught in the contexts of these texts, as was done in this course when teacher educators analyzed with the EFL pre-service teachers the structures of the sample texts they had brought to class or the structures they had used in their information report drafts.

\section{Conclusions}

All in all, the study presented here suggests that even though taking an SFL GBI approach to the teaching of EFL writing presents both gains and challenges for EFL pre-service teachers, it is worth it. Indeed, it helps them to develop a more contextual, purposeful, and reader-oriented view of writing and presents them with a more functional view of grammar that, although difficult to internalize, can better help them in the long run in their courses and future professional work. The study also suggests that one single teaching cycle following this methodology is not enough to completely switch EFL pre-service teachers' views of writing as a fixed activity or their views of grammar as a system of rules.

These teachers in preparation need to experience this methodology consistently through different units and courses, and to be provided with a lot of opportunities to practice writing different genres for different purposes and audiences. This way, they will have time to notice the lexical, grammatical, and textual demands of each genre more deeply. They will also have time to understand more clearly how these are shaped by context, purpose, and audience; and experience grammar in a more meaningful and contextualized way. Then, and only then, can they be considered to be ready "to accomplish [the] wide variety of social, academic and 
political goals in and out of school" (Gebhard et al. Harman, \& Seger, 2007, p. 421) that teacher preparation programs set out for them.

\section{References}

Achugar, M., Schleppegrell, M. J., \& Oteíza, T. (2007). Engaging teachers in language analysis: A functional linguistics approach to reflective literacy. English Teaching: Practice and Critique, 6(2), 8-24.

Butt, D., Fahey, R., Feez, S., Spinks, S., \& Yallop, C. (2000). Using functional grammar: An explorer's guide. Sydney, AU: Macquarie University.

Chaisiri, T. (2010). Implementing a genre pedagogy to the teaching of writing in a university context in Thailand. Language Education in Asia, 1, 181-199. https://doi.org/10.5746/LEiA/10/ V1/A16/Chaisiri.

Chala, P. A., \& Chapetón, C. M. (2013). The role of genre-based activities in the writing of argumentative essays in EFL. PROFILE Issues in Teachers' Professional Development, 15(2), 127-147.

De Oliveira, L. C., \& Lan, S.-W. (2014). Writing science in an upper elementary classroom: A genre-based approach to teaching English language learners. Journal of Second Language Writing, 25, 23-39. https://doi.org/10.1016/j.jslw.2014.05.001.

Defazio, J., Jones, J., Tennat, F., Hook, S. A. (2010). Academic literacy: The importance and impact of writing across the curriculum - a case study. Journal of the Scholarship of Teaching and Learning, 10(2), 34-47.

Derewianka, B. (2004). Exploring how texts work. Victoria, AU: Primary English Teaching Association.

Fang, Z., \& Schleppegrell, M. J. (2010). Disciplinary literacies across content areas: Supporting secondary reading through functional language analysis. Journal of Adolescent \& Adult Literacy, 53(7), 587-597. https://doi.org/10.1598/JAAL.53.7.6.

Feez, S. (2002). Heritage and innovations in second language education. In A. M. Johns (Ed.), Genre in the classroom: Multiple perspectives (pp. 43-72). Mahwah, US: Lawrence Erlbaum Associates.

Gebhard, M., \& Harman, R. (2011). Reconsidering genre theory in K-12 schools: A response to school reforms in the United States. Journal of Second Language Writing, 20(1), 45-55. https:// doi.org/10.1016/j.jslw.2010.12.007.

Gebhard, M., Harman, R., \& Seger, W. (2007). Reclaiming recess in urban schools: The potential of systemic functional linguistics for ELLs and their teachers. Language Arts, 84(5), 419-430.

Halliday, M. A. K. (1978). Language as social semiotic: The social interpretation of language and meaning. London, UK: Edward Arnold.

Hyland, K. (2002). Genre: Language, context, and literacy. Annual Review of Applied Linguistics, 22, 113-135. https://doi.org/10.1017/s0267190502000065.

Hyland, K. (2003). Genre-based pedagogies: A social response to process. Journal of Second Language Writing, 12(1), 17-29. https://doi.org/10.1016/S1060-3743(02)00124-8.

Hyland, K. (2004). Disciplinary discourses: Social interactions in academic writing. Ann Arbor, US: The University of Michigan Press. https://doi.org/10.3998/mpub.6719. 
Hyon, S. (1996). Genre in three traditions: Implications for ESL. TESOL Quarterly, 30(4), 693-722. https://doi.org/10.2307/3587930.

Hyon, S. (2002). Genre and ESL reading: A classroom study. In A. M. Johns (Ed.), Genre in the classroom: Multiple perspectives (pp. 121-144). Mahwah, US: Lawrence Erlbaum Associates.

Johns, A. M. (1997). Text, role, and context: Developing academic literacies. Cambridge, UK: Cambridge University Press. https://doi.org/10.1017/CBO9781139524650.

Johns, A. M. (Ed.). (2002). Genre in the classroom: Multiple perspectives. Mahwah, US: Lawrence Erlbaum Associates.

Johns, A. M. (2011). The future of genre in L2 writing: Fundamental, but contested, instructional decisions. Journal of Second Language Writing, 20(1), 56-68. https://doi.org/10.1016/j. jslw.2010.12.003.

Lee, I. (2012). Genre-based teaching and assessment in secondary English classrooms. English Teaching: Practice and Critique, 11(4), 120-136.

Macken-Horarik, M. (2002). "Something to shoot for": A systemic functional approach to teaching genre in secondary school science. In A. M. Johns (Ed.), Genre in the classroom: Multiple perspectives (pp. 17-42). Mahwah, US: Lawrence Erlbaum Associates.

Martin, J. R. (2009). Genre and language learning: A social semiotic perspective. Linguistics and Education, 20(1), 10-21. https://doi.org/10.1016/j.linged.2009.01.003.

Matsuda, P. K. (1999). Composition studies and ESL writing: A disciplinary division of labor. College Composition and Communication, 50(4), 699-721. https://doi.org/10.2307/358488.

Matsuda, P. K. (2006). Second-language writing in the twentieth century: A situated historical perspective. In P. K. Matsuda, M. Cox, J. Jordan, \& C. Ortmeier-Hooper (Eds.), Second-language writing in the composition classroom: A critical sourcebook (pp. 14-30). Boston, US: Bedford/St. Martin's.

Schleppegrell, M. J. (2004). The language of schooling: A functional linguistics perspective. Mahwah, US: Lawrence Erlbaum Associates.

Schleppegrell, M. J., \& Go, A. L. (2007) Analyzing the writing of English learners: A functional approach. Language Arts, 84(6), 529-538.

Silva, T., \& Matsuda, P. K. (2002). Writing. In N. Schmitt (Ed.), An introduction to applied linguistics (pp. 250-266). London, UK: Arnold.

Suter, W. N. (2012). Introduction to educational research: A critical thinking approach. Little Rock, US: Sage Publications. https://doi.org/10.4135/9781483384443.

Vygotsky, L. (1978). Mind in society: The development of higher psychological processes. Cambridge, US: Harvard University Press.

Yasuda, S. (2011). Genre-based tasks in foreign language writing: Developing writers' genre awareness, linguistic knowledge, and writing competence. Journal of Second Language Writing, 20(2), 111-133. https://doi.org/10.1016/j.jslw.2011.03.001. 


\section{The Authors}

Doris Correa holds a Doctorate degree in Language, Literacy, and Culture from the University of Massachusetts, Amherst. Currently, she works as an Associate Professor at the School of Languages, Universidad de Antioquia, where she has done research in English language policy, critical literacies, systemic functional linguistics, and linguistic landscapes.

Sandra Echeverri holds a Masters' degree in Foreign Language Teaching and Learning from Universidad de Antioquia. Currently, she works as a lecturer at the School of Languages, Universidad de Antioquia, where she has done research in assessment in foreign languages and academic literacies as part of the GIAE research group. 